\title{
Pengaruh Penghindaran Pajak (Tax Avoidance) Pada Nilai Perusahaan Dengan Transparansi Sebagai Variabel Pemoderasi
}

\author{
Made Caesar Juliartha Nugraha ${ }^{1}$ \\ Putu Ery Setiawan ${ }^{2}$ \\ ${ }^{1,2}$ Fakultas Ekonomi dan Bisnis Universitas Udayana (Unud), Bali, Indonesia \\ e-mail: caesarjuliartha@yahoo.com
}

\begin{abstract}
ABSTRAK
Pajak adalah kontribusi wajib kepada negara yang terutang oleh orang pribadi atau badan yang bersifat memaksa berdasarkan Undang-Undang dengan tidak mendapatkan imbalan secara langsung dan digunakan untuk keperluan negara bagi sebesar-besarnya kemakmuran rakyat. Tujuan penelitian ini adalah untuk mengetahui pengaruh penghindaran pajak (tax avoidance) pada nilai perusahaaan dengan transparansi sebagai variabel pemoderasi. Penelitian ini dilaksanakan pada perusahaan manufaktur yang terdaftar di Bursa Efek Indonesia tahun 2014-2016. Jumlah sampel yang digunakan dalam penelitian ini sebanyak 60 perusahaan dengan jumlah observasi 180 yang diperoleh dengan teknik non-probability sampling dengan metode purposive sampling. Teknik analisis data dilakukan dengan menggunakan teknik analisis moderated regression analysis. Hasil penelitian yang dilakukan menunjukkan bahwa penghindaran pajak (tax avoidance) berpengaruh positif pada nilai perusahaan. Penelitian ini juga menemukan bahwa transparansi mampu memoderasi pengaruh penghindaran pajakpada nilai perusahaan.
\end{abstract}

Kata kunci: Penghindaran Pajak, Transparansi, Nilai Perusahaan

\begin{abstract}
Tax is a compulsory contribution to the state owed by an individual or entity that is a force based on the Law by not getting compensation directly and used for state needs for the greatest prosperity of the people. The purpose of this study was to determine the effect of tax avoidance (tax avoidance) on company value with transparency as a moderating variable. This research was conducted at manufacturing companies listed on the Indonesia Stock Exchange in 2014-2016. The number of samples used this study were 60 companies with the number of observations 180 obtained by non-probability sampling techniques with purposive sampling method. Data analysis techniques were carried out using moderated regression analysis. The results of the research conducted show that tax avoidance (tax avoidance) has a positive effect firm value. The study also found that transparency was able to moderate the effect of tax avoidance on firm value.
\end{abstract}

Keywords: Tax Avoidance, Transparency, Corporate Value

\section{PENDAHULUAN}

Pembangunan nasional merupakan salah satu kegiatan pemerintah yang berlangsung secara terus menerus dan berkesinambungan yang bertujuan untuk meningkatkan kesejahteraan masyarakat. Salah satu usaha bangsa agar bisa mandiri dalam pembiayaan pembangunan adalah dengan cara menggali sumber 
pendapatan pemerintah (Olaofe, 2008). Sumber pendapatan pemerintah berasal dari pendapatan pajak dan pendapatan non pajak (Alabede dkk., 2011). Penerimaan negara dari sektor pajak merupakan salah satu sumber peneriman negara yang penting. Bahkan dengan diberlakukannya Undang Undang otonomi daerah maka penerimaan negara khususnya penerimaan dari sektor pajak memiliki peranan yang sangat besar bagi peningkatan jumlah dana pembangunan nasional dan pembiayaan rutin. Menyadari akan besarnya peranan pajak untuk menggerakkan roda pemerintah dan pembangunan maka sejak tahun 1983 telah dilakukan usaha usaha dalam bentuk reformasi sistem perpajakan nasional secara terus menerus.

Menurut Undang-Undang No. 16 Tahun 2009 tentang Ketentuan Umum dan Tata Cara Perpajakan pada pasal 1 ayat 1 adalah kontribusi wajib kepada negara yang terutang oleh orang pribadi atau badan yang bersifat memaksa berdasarkan Undang-Undang dengan tidak mendapatkan imbalan secara langsung dan digunakan untuk keperluan negara bagi sebesar-besarnya kemakmuran rakyat. Wajib pajak dalam hal ini adalah sekumpulan orang dan atau modal yang merupakan kesatuan baik yang melakukan usaha maupun yang tidak melakukan usaha yang meliputi perseroan terbatas, perseroan komanditer, perseroan lainnya, badan usaha milik negara atau badan usaha milik daerah dengan nama dan dalam bentuk apa pun, firma, kongsi, koperasi, dana pensiun, persekutuan, perkumpulan, yayasan, organisasi massa, organisasi sosial politik, atau organisasi lainnya, lembaga dan bentuk badan lainnya termasuk kontrak investasi kolektif dan bentuk usaha tetap (Dharma, 2016). 
Definisi tersebut menegaskan bahwa pajak merupakan salah satu sumber penerimaan negara. Pajak memiliki manfaat sebagai sumber dana bagi pemerintah yang digunakan untuk membiayai pengeluaran negara (fungsi budgetair) dan sebagai alat untuk mengatur atau melaksanakan kebijakan pemerintah dalam bidang sosial dan ekonomi (fungsi regulator) (Mardiasmo, 2016). Pemerintah setiap tahunnya selalu menaikkan target penerimaan dari sektor perpajakan. Perpajakan Indonesia sendiri dikelola pemerintah melalui Direktorat Jenderal Pajak yang berada di bawah Departemen Keuangan.

Pemerintah setiap tahunnya selalu meningkatkan target penerimaan dari sektor pajak, namun kenyataannya realisasi penerimaan dari sektor pajak selalu lebih rendah dari yang sudah ditargetkan. Berdasarkan data dari liputan6.com, efektivitas pemungutan pajak terus mengalami penurunan dari tahun $2014-2016$. Efektivitas pemungutan pajak di Indonesia dapat dilihat pada Tabel 1. berikut.

\section{Tabel 1.}

Efektivitas Pemungutan Pajak di indonesia

\begin{tabular}{cccc}
\hline \multirow{2}{*}{ Tahun } & Target & Realisasi & Efektifitas Pemungutan Pajak \\
\hline 2014 & 1.246 Triliun & 1.143 Triliun & $91,75 \%$ \\
2015 & 1.294 Triliun & 1.060 Triliun & $81,91 \%$ \\
2016 & 1.355 Triliun & 1.105 Triliun & $81.54 \%$ \\
\hline
\end{tabular}
Sumber: www.liputan6.com, 2018

Berdasarkan Tabel 1. dapat dilihat bahwa tingkat efektivitas penerimaan pajak tiap tahunnya dari tahun 2014 - 2016 mengalami penurunan. Target penerimaan pajak yang tidak tercapai tersebut dikarenakan salah satu penyebab adalah adanya tindakan penghindaran pajak yang dilakukan oleh perusahaan (Dharma, 2016). Penghindaran pajak bisa terjadi karena pada intinya pemegang saham pada setiap perusahaan tentu ingin mendapatkan return yang tinggi karena 
sudah menanamkan modalnya di perusahaan tersebut, dengan mengurangi jumlah pajak yang terutang, perusahaan bisa meningkatkan keuntungannya. Menurut Kurniasih dan Sari (2013) bagi sebuah perusahaan, pajak merupakan beban yang akan mengurangi pendapatan atau laba bersih dan sudah menjadi rahasia umum bahwa perusahaan selalu menginginkan pembayaran pajak seminimal mungkin, sedangkan pemerintah menginginkan pajak setinggi mungkin guna membiayai penyelenggaraan pemerintahan.

Pemerintah menyusun berbagai kebijakan dalam bentuk intensifikasi dan ekstensifikasi dalam rangka meningkatkan penerimaan negara dari sektor pajak. Upaya pemerintah dalam meningkatkan penerimaan pajak ternyata berlawanan dengan kepentingan para wajib pajak pribadi maupun badan yang sebisa mungkin untuk menghindari pembayaran pajak. Perusahaan sebagai salah satu wajib pajak memandang pajak sebagai beban bagi perusahaan. Bagi perusahaan, pajak yang dikenakandapat memengaruhi posisi keuangan perusahaan, kinerja keuangan, likuiditas, hasil operasi, dan arus kas terhadap penghasilan yang diterima. Perusahaan cenderung untuk mengurangi beban pajak dalam memperbaiki kinerja perusahaan (Prasiwi, 2015).

Perusahaan melakukan berbagai cara untuk meminimalkan beban pajak yang akan dibayar, salah satunya yaitu dengan manajemen pajak. Menurut Chen (2014) manajemen pajak adalah sarana untuk memenuhi kewajiban perpajakan dengan benar tetapi jumlah pajak yang harus dibayar dapat ditekan serendah mungkin untuk memperoleh laba dan likuiditas yang diharapkan. Manajemen 
pajak merupakan upaya dalam melakukan penghematan pajak secara legal. Tax avoidance merupakan salah satu bentuk manajemen pajak.

Penghindaran pajak (tax avoidance) tidak sama dengan penggelapan pajak (tax evasion). Menurut Dewi dan Lely (2016) penghindaran pajak (tax avoidance) merupakan cara mengurangi pajak yang masih dalam batas ketentuan perundangundangan perpajakan dan dapat dibenarkan melalui perencanaan perpajakan, sedangkan tax evasion adalah usaha mengurangi beban pajak dengan cara yang ilegal, misalnya melaporkan pendapatan dibawah yang sebenarnya ataupun tingkat pengurang yang tinggi, secara garis besar perbedaan utama terletak pada sisi legalitas. Jacob (2014) mendefinisikan tax avoidance sebagai suatu tindakan untuk melakukan pengurangan atau meminimalkan kewajiban pajak dengan hatihati mengatur sedemikian rupa untuk mengambil keuntungan dari celah-celah dalam ketentuan pajak, seperti pengenaan pajak melalui transaksi yang bukan merupakan objek pajak.

Fenomena yang terjadi tentang penghindaran pajak dapat ditemukan pada kasus Google. Google adalah sebuah perusahaan multinasional dari Amerika Serikat yang berkekhususan pada jasa dan produk internet. Seperti dilansir liputan6.com Google mendirikan induk usaha di Singapura yang tersohor sebagai negara surga pajak dengan tarif pajaknya yang rendah untuk menangani bisnisnya di ASIA termasuk Indonesia. Google merasa tidak pernah ada Bentuk Usaha Tetap (BUT) di Indonesia karena faktanya seluruh kontrak dijalankan tanpa melalui kantor perwakilan di negara ini, seluruh kontrak yang dilakukan antara Google dengan konsumen di Indonesia berlangsung secara online. BUT 
merupakan satu syarat atau ambang batas negara sumber penghasilan bisa memungut pajak. Tanpa BUT, tax treaty tidak berhak memajaki penghasilannya yang didapat dari iklan secara online.

Penghindaran pajak telah terjadi sekian lama yang dilakukan oleh perusahaan-perusahan besar di dunia. Peningkatan nilai perusahaan merupakan tujuan perusahaan yang dapat dicapai melalui pelaksanaan fungsi manajemen, dimana suatu keputusan yang diambil akan mempengaruhi keputusan lainnya dan nantinya akan berdampak pada nilai perusahaan. Peningkatan nilai perusahaan dapat terlihat pada kenaikan harga saham perusahaan. Nilai perusahaan yang tinggi akan menjadi sinyal positif yang dapat meningkatkan kesejahteraan bagi investor untuk menanamkan modalnya di perusahaan tersebut.

Penghindaran pajak (tax avoidance) merupakan salah satu keputusan manajemen yang diharapkan dapat meningkatkan nilai perusahaan. Berdasarkan penelitian terdahulu mengenai pengaruh penghindaran pajak (tax avoidance) pada nilai perusahaan, terdapat ketidak konsistenan hasil. Penelitian yang dilakukan Anggoro \& Septiani (2015) menyatakan bahwa perilaku penghindaran pajak berpengaruh positif pada nilai perusahaan. Hal ini juga didukung oleh penelitian yang dilakukan Kurniawan dan Syafruddin (2017), Dewi dan Dewi (2017), Hanlon dan Slemrod (2009), Wang (2010) yang menghasilkan bukti empiris bahwa perilaku penghindaran pajak berpengaruh positif pada nilai perusahaan. Hasil yang berbeda didapat oleh Ilmiani dan Sutrisno (2014), Ftouhi, Ayed, dan Zemzem (2015), Tarihoran (2016), Desai dan Dharmapala (2005) yang menyatakan bahwa penghindaran pajak memiliki pengaruh negatif pada nilai 
perusahaan. Sedangkan penelitian yang dilakukan Prasiwi (2015), Siregar (2012), Rikotama (2018) menyatakan bahwa tax avoidance tidak berpengaruh pada nilai perusahaan.

Investor sebagai principal menganggap penghindaran pajak adalah tindakan yang tidak patuh terhadap undang-undang perpajakan dan menyebabkan timbulnya biaya di kemudian hari akibat adanya pemeriksaaan pajak, ketika penghindaran pajak tersebut terungkap. Manajer sebagai agen memandang kebijakan penghindaran pajak adalah cara untuk meminimumkan beban pajak secara legal dengan memanfaatkan celah celah dari peraturan perpajakan sehingga dapat meningkatkan laba perusahaan yang berpengaruh positif pada nilai perusahaan. Timbulnya konflik kepentingan ini terjadi karena adanya asimetri informasi sehingga mengakibatkan adanya perbedaan persepsi antara investor dan manajer tentang kebijakan penghindaran pajak.

Untuk mengatasi masalah agensi tersebut sangat relevan dalam mempertimbangkan transparansi sebagai moderasi hubungan antara penghindaran pajak dan nilai perusahaan. Konflik kepentingan (agency conflict) ini dapat diminimalisir dengan adanya transparansi (Armstrong dkk., 2015). Menurut Wang (2010) transparansi merupakan ketersediaan informasi spesifik perusahaan kepada pemegang saham luar yang mempengaruhi nilai perusahaan. Transparansi menjadi alat untuk mengawasi setiap tindakan manajer sehingga mengurangi kecemasan investor terhadap biaya agensi tersembunyi terkait penghindaran pajak. Biaya agensi merupakan biaya yang timbul karena tindakan manajer yang berbeda dari tindakan untuk memaksimumkan kepentingan pemegang saham. 
Adanya transparansi diharapkan dapat mengurangi perilaku oportunistik manajer. Berdasarkan penelitian terdahulu mengenai transparansi sebagai variabel pemoderasi hubungan penghindaran pajak (tax avoidance) pada nilai perusahaan, terdapat ketidak konsistenan hasil. Penelitian yang dilakukan oleh Anggoro dan Septiani (2015), Akhunianov (2009), Pradnyana dan Noviari (2017), Ilmiani dan Sutrisno (2014), Dewi dan Dewi (2017), Prasiwi (2015) yang meyatakan bahwa transparansi mampu memoderasi pengaruh tax avoidance pada nilai perusahaan. Hasil yang berbeda didapat oleh Aina (2016) yang menyatakan bahwa transparansi tidak mampu memoderasi pengaruh tax avoidance pada nilai perusahaan.

Penelitian ini memfokuskan sampel penelitian pada salah satu sektor kelompok perusahaan yang terdaftar di Bursa Efek Indonesia (BEI), yaitu perusahaan manufaktur. Perusahaan manufaktur seluruh aktivitas usaha mulai dari pembelian bahan baku hingga menjadi barang jadi dan siap untuk dijual ke pasaran sebagian usahanya terkait dengan aspek perpajakan. Perusahaan manufaktur juga memiliki jumlah perusahaan yang paling banyak dibandingkan jenis usaha lain yang terdiri dari beberapa industri.

Teori agensi menjelaskan bahwa sumber daya yang dimiliki oleh perusahaan dapat digunakan oleh agen untuk memaksimalkan kompensasi kinerja agen, yaitu dengan cara menekan beban pajak perusahaan untuk memaksimalkan kinerja perusahaan. Agen akan berusaha mengelola beban pajak perusahaan agar tidak mengurangi kompensasi kinerja agen sebagai akibat dari berkurangnya nilai perusahaan karena beban pajak yang besar. 
Penghindaran pajak berkenaan dengan pengaturan sesuatu peristiwa sedemikian rupa untuk meminimkan beban pajak dengan memperhatikan ada atau tidaknya akibat-akibat pajak yang ditimbulkan. Penghindaran pajak tidak merupakan pelanggaran atas perundang-undangan perpajakan atau secara etik tidak dianggap salah dalam rangka usaha wajib pajak untuk meminimumkan atau meringankan beban pajak dengan cara-cara yang dimungkinkan oleh undangundang pajak. Pada dasarnya penghindaran pajak dapat meningkatkan nilai perusahaan karena terjadi pengambilalihan potensi kekayaan yang diberikan kepada pemegang saham. Pemberian keuntungan ini nantinya dapat meningkatkan loyalitas perusahaan sehingga dapat diindikasikan nilai perusahaan akan meningkat. Penghindaran pajak dilakukan dengan cara meminimalkan jumlah pajak yang dibayar untuk memperoleh laba yang tinggi sehingga dapat meningkatkan nilai perusahaan.

Berdasarkan uraian diatas, pernyataan tersebut diperkuat oleh penelitian yang dilakukan oleh Anggoro dan Septiani (2015), Kurniawan dan Syafruddin (2017), Hanlon dan Slemrod (2009), dan Wang (2010), Dewi dan Dewi (2017) menyatakan bahwa penghindaran pajak berpengaruh positif pada nilai perusahaan. Berdasarkan uraian diatas, maka dapat dirumuskan hipotesis sebagai berikut.

$\mathrm{H}_{1}$ : Penghindaran pajak berpengaruh positif pada nilai perusahaan

Perusahaan yang transparan mempunyai akses informasi penting yang dapat diakses oleh investor ketika diperlukan, sehingga hal tersebut menjadi sinyal positif bagi investor. Berdasarkan teori sinyal dimana perusahaan yang memberikan informasi yang bagus akan membedakan mereka dengan perusahaan 
yang tidak memiliki berita bagus dengan menginformasikan pada pasar tentang keadaan mereka. Pada dasarnya nilai perusahaan dapat dikatakan baik salah satunya ditunjukkan oleh peningkatan harga saham perusahaan dari waktu ke waktu.

Transparansi informasi diharapkan mampu membantu mengurangi masalah agensi konflik antara pemilik perusahaan dan manajer. Transparansi informasi memudahkan investor untuk mendapatkan akses informasi terkait perusahaan. Akses informasi tersebut dianggap oleh investor sebagai cara mudah untuk memperhatikan perilaku oportunistik dari manajemen dalam melakukan tindakan penghindaran pajak sehingga menurunkan risiko yang timbul dari kegiatan penghindaran pajak (Bushman dkk., 2003).

Berdasarkan uraian diatas, pernyataan tersebut diperkuat oleh penelitian yang dilakukan oleh Ilmiani dan Sutrisno (2014), Partha (2016), Anggoro dan Septiani (2015), Pradnyana dan Noviari (2017), Wang (2010), Dewi dan Dewi (2017) dan Akhunianov (2009) menyatakan bahwa tranparansi mampu memoderasi pengaruh penghindaran pajak pada nilai perusahaan. Berdasarkan uraian diatas, maka dapat dirumuskan hipotesis sebagai berikut.

$\mathrm{H}_{2}$ : Transparansi mampu memoderasi pengaruh penghindaran pajak pada nilai perusahaan

\section{METODE PENELITIAN}

Penelitian ini menggunakan pendekatan kuantitatif yang berbentuk asosiatif. Penelitian ini menjelaskan tentang pengaruh penghindaran pajak (tax avoidance) 
pada nilai perusahaan dengan transparansi sebagai variabel pemoderasi. Sistematis kerangka konseptual dari penelitian ini dapat dilihat pada Gambar 1. berikut.



Sumber: Data Diolah, 2018

\section{Gambar 1. Kerangka Konseptual}

Lokasi penelitian dilakukan di Bursa Efek Indonesia (BEI) dengan mengakses situs resmi BEI yaitu www.idx.co.id. Penelitian ini dilakukan pada perusahaan manufaktur yang terdaftar di BEI periode 2014-2016. Pemilihan perusahaan manufaktur karena perusahaan tersebut melakukan aktivitas usaha secara menyeluruh mulai dari pembelian bahan baku hingga menjadi barang jadi dan siap untuk dijual ke pasaran sebagian usahanya terkait dengan aspek perpajakan. Objek dari penelitian ini adalah nilai perusahaan yang dipengaruhi oleh praktik penghindaran pajak dan transparansi. Transparansi dalam penelitian ini berfungsi sebagai pemoderasi pengaruh antara variabel independen dan dependen.

Variabel terikat dalam penelitian ini adalah Nilai Perusahaan (Y). Nilai perusahaan dalam penelitian ini diukur menggunakan rasio Tobin's $Q$. Rasio Tobin's $Q$ digunakan karena merefleksikan ekspektasi pasar sehingga relatif bebas dari kemungkinan manipulasi oleh manajemen perusahaan. Rasio ini dinilai dapat memberikan informasi yang paling baik, rasio ini dapat menjelaskan berbagai 
Made Caesar Juliartha Nugraha dan Putu Ery Setiawan. Pengaruh...

fenomena yang terjadi dalam kegiatan perusahaan seperti terjadinya perbedaan crossectional dalam pengambilan keputusan investasidengan rumus perhitungansebagai berikut.

$$
\text { Tobin's } Q=\frac{\text { Total Market Value }+ \text { Total Book Value of Liabilities }}{\text { Total Book Value of Assets }}
$$

Keterangan:

Total Market Value $=$ Harga saham penutupan $\times$ jumlah saham yang beredar

Total Book Value Of Liabilities= Utang lancar + utang jangka panjang

Total Book Value Of Assets $=$ Total aset

Variabel bebas dalam penelitian ini adalah Penghindaran Pajak $\left(\mathrm{X}_{1}\right)$. Penelitian ini menggunakan proksi Effective Tax Rate (ETR) sebagai pengukuran penghindaran pajak. ETR digunakan dalam mengukur penghindaran pajak, karena perusahaan-perusahaan yang menghindari pajak cenderung akan mengurangi penghasilan kena pajak dengan tetap menjaga laba akuntansi keuangannya,sehingga perusahaan memiliki nilai ETR yang lebih rendah.Rumus untuk menghitung ETR adalah sebagai berikut.

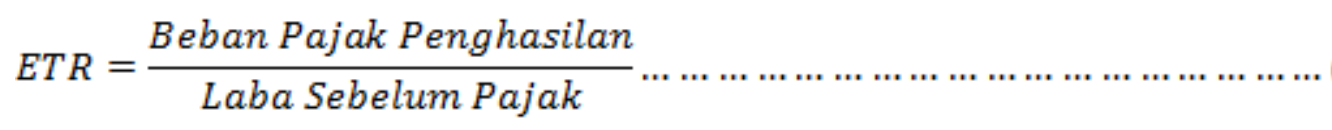

Variabel moderasi dalam penelitian ini adalah Transparansi $\left(\mathrm{X}_{2}\right)$. Pengukuran transparansi informasi menggunakan proksi voluntary disclosure, yaitu pengungkapan yang dilakukan secara sukarela oleh perusahaan tanpa diharuskan oleh peraturan yang berlaku. Pengukuran transparansi informasi dilakukan melalui dua tahap, pertama yaitu pengembangan butir-butir pengungkapan sukarela dan kedua adalah mencari angka indeks pengungkapan 
sukarela. Butir-butir pengungkapan sukarela dalam laporan tahunan terdiri dari 50 item informasi yang telah dikembangkan dan disesuaikan dengan peraturan Bapepam-LK Keputusan nomor Kep-431/BL/2012. Untuk proksi pengukurannya menggunakan prosedur ceklist dengan skor 1 jika perusahaan mengungkapkan item dan skor 0 jika tidak mengungkapkan item. Sehingga tingkat pengungkapan sukarela dihitung sebagai berikut.

$$
\text { DISC }=\frac{\text { jumlah item yang diungkapkan perusahaan }}{\text { jumlah } \text { keseluruhan item indeks }}
$$

Populasi dalam penelitian ini adalah seluruh perusahaan manufaktur yang terdaftar di Bursa Efek Indonesia (BEI) pada tahun 2014 sampai dengan 2016 yang berjumlah 142 perusahaan. Sampel dalam penelitian ini adalah perusahaan manufaktur yang terdaftar di BEI selama periode tahun 2014-2016. Metode penentuan sampel dalam penelitian ini adalah berdasarkan pendekatan purposive sampling, yaitu teknik penentuan sampel dengan kriteria tertentu. Perusahaan yang tidak sesuai dengan kriteria yang ditetapkan peneliti akan dikeluarkan dari sampel.

Jenis data yang digunakan dalam penelitian ini adalah Data kuantitatif berupa angka-angka laporan keuangan perusahaan manufaktur yang terdaftar di BEI periode tahun 2014-2016. Data kualitatif berupa daftar nama-nama perusahaan manufaktur yang terdaftar di BEI periode tahun 2014-2016. Sedangkan sumber data yang digunakan dalam penelitian ini adalah Data sekunder berupa laporan keuangan perusahaan manufaktur yang terdaftar di Bursa Efek Indonesia (BEI) pada periode tahun 2014-2016 dan dapat diakses dari www.idx.co.id atau dari situs resmi dari masing-masing perusahaan. 
Metode pengumpulan data yang digunakan dalam penelitian ini adalah observasi non participant, yaitu dengan membaca, mengumpulkan, mencatat datadata, informasi, dan keterangan dimana peneliti tidak terlibat secara langsung dan hanya sebagai pengamat independen (Sugiyono, 2016). Data yang dimaksudkan adalah data publikasi laporan keuangan tahunan perusahaan manufaktur yang telah terdaftar pada BEI dan sesuai dengan kriteria pemilihan sampel.

Teknik analisis data yang digunakan dalam penelitian ini adalah teknik analisis Moderated Regression Analysis (MRA). Uji MRA merupakan aplikasi khusus linier berganda. MRA dalam persamaan regresinya mengandung interaksi, yaitu perkalian dua atau lebih variabel independen. MRA digunakan untuk menguji hubungan penghindaran pajak pada nilai perusahaan dimana transparansi sebagai variabel pemoderasi. Persamaan regresi dari model regresi moderasi adalah.

$$
Y=\alpha+\beta_{1} X_{1}+\beta_{2} X_{2}+\beta_{3} X_{1} X_{2}+\mu
$$

\section{Keterangan:}

$\mathrm{Y}=$ nilai perusahaan

$\alpha \quad=$ konstanta

$\mathrm{X}_{1} \quad=$ penghindaran pajak

$\mathrm{X}_{2} \quad=$ transparansi

$\beta_{1}-\beta_{3}=$ koefisien regresi

$\mathrm{X}_{1} \mathrm{X}_{2}=$ interaksi antara penghindaran pajak dengan transparansi

$\mu \quad=$ standard error

Sebelum dilakukan pengujian hipotesis, data terlebih dahulu diuji asumsi klasik. Hal ini dilakukan untuk menghindari terjadinya estimasi bias mengingat tidak semua data dapat diterapkan regresi. Pengujian asumsi klasik meliputi uji normalitas, uji multikolinieritas uji autokorelasi dan uji heteroskedastisitas. 


\section{HASIL DAN PEMBAHASAN}

Populasi yang digunakan dalam penelitian ini adalah seluruh perusahaan manufaktur yang terdaftar di Bursa Efek Indonesia (BEI) pada tahun 2014 sampai dengan 2016 yaitu sebanyak 142 perusahaan. Pengambilan sampel dalam penelitian ini menggunakan teknik non probability sampling dan metode pengambilan sampel yang digunakan dalam penelitian ini adalah metode purposive sampling sehingga sampel yang diperoleh sebanyak 60 sampel dan jumlah data amatan dengan pengamatan selama 3 tahun sebanyak 180 sampel perusahaan.

Perusahaan dipilih dengan menggunakan teknik purposive sampling sesuai dengan kriteria yang telah ditetapkan. Proses penyeleksian sampel dalam penelitian ini adalah sebaga berikut dalam Tabel 2 .

Tabel 2.

\section{Proses Seleksi Sampel}

Keterangan
selama periode 2014-2016.

Perusahaan manufaktur yang tidak menerbitkan laporan keuangan pada periode 2014-2016 dan telah diaudit.

Perusahaan yang mengalami kerugian selama periode 2014-2016. Jumah perusahaan yang terpilih sebagai sampe Total sampel dalam tiga tahun penelitian Sumber: Data Diolah, 2018

Analisis statistik desktiptif merupakan gambaran atau deskripsi data yang dilihat dari nilai maksimum, nilai minimum, nilai rata-rata (mean), dan standar Jumlah

142 180 
deviasi. Hasil statistik deskriptif masing-masing variabel dalam penelitian ini dapat dlihat pada Tabel 3. berikut.

Tabel 3.

Hasil Uji Statistik Deskriptif

\begin{tabular}{llllll}
\hline Variabel & N & Min. & Max. & Mean & $\begin{array}{l}\text { Std. } \\
\text { Deviasi }\end{array}$ \\
\hline ETR $\left(\mathrm{X}_{1}\right)$ & 180 & 0,03 & 9,89 & 0,4166 & 0,85565 \\
Transparansi $\left(\mathrm{X}_{2}\right)$ & 180 & 0,58 & 0,96 & 0,8237 & 0,06623 \\
\hline Variabel & $\mathbf{N}$ & Min. & Max. & Mean & $\begin{array}{l}\text { Std. } \\
\text { Deviasi }\end{array}$ \\
\hline Nilai Perusahaan $(\mathrm{Y})$ & 180 & 0,29 & 13,16 & 1,9878 & 2,26161 \\
\hline Sumb & & & & &
\end{tabular}

Sumber: Data diolah, 2018

Berdasarkan Tabel 3. dapat disimpulkan bahwa nilai perusahaan pada perusahaan manufaktur yang terdaftar di BEI tahun 2014-2016 memiliki nilai rata-rata sebesar 1,9878 dengan nilai standar deviasi adalah sebesar 2,26161. Perusahaan yang memiliki nilai perusahaan terkecil adalah Intanwijaya Internasional Tbk yaitu sebesar 0,29 pada tahun observasi 2016. Perusahaan dengan nilai perusahaan terbesar dimiliki oleh Semen Baturaja Persero Tbk sebesar 13,16 pada tahun observasi 2016. Standar deviasi yang menunjukkan lebih tinggi dari rata-ratanya berarti bahwa varians nilai perusahaan dari seluruh sampel lebih kecil dari rata-ratanya.

Variabel bebas penghindaran pajak (tax avoidance) yang diproksikan melalui ETR pada perusahaan manufaktur memiliki nilai rata-rata sebesar 0,4166 dengan nilai standar deviasi adalah sebesar 0,85565 . Perusahaan yang memiliki ETR terkecil adalah Aneka Gas Industri Tbk sebesar 0,03 pada tahun observasi 2016. Perusahaan dengan ETR terbesar dimiliki oleh Indospring Tbk sebesar 9,89 pada tahun observasi 2015. Standar deviasi yang menunjukkan lebih tinggi dari 
rata-ratanya berarti bahwa varians penghindaran pajak dari seluruh sampel lebih kecil dari rata-ratanya.

Variabel transparansi memiliki nilai rata-rata sebesar 0,8237 dengan nilai standar deviasi adalah sebesar 0,06623. Perusahaan yang memiliki nilai transparansi terkecil adalah Cahaya Kalbar Tbk sebesar 0,58 pada tahun observasi 2014. Perusahaan dengan nilai transparansi terbesar adalah Kabelindo Murni Tbk sebesar 0,96 pada tahun observasi 2015 dan 2016. Standar deviasi yang menunjukkan lebih rendah dari rata-ratanya berarti bahwa varians transparansi informasi dari seluruh sampel lebih besar dari rata-ratanya.

Suatu model regresi akan dapat dijadikan alat estimasi yang tidak bias jika telah memenuhi persyaratan best linear unbiased estimator (BLUE) yaitu data terdistribusi normal, tidak terjadi multikolinieritas, tidak terjadi heteroskedastisitas dan tidak terjadi autokorelasi. Untuk itu maka dilakukan uji model regresi harus dilakukan dengan pengujian asumsi klasik terhadap model regresi yang akan digunakan. Uji asumsi klasik dalam penelitian ini meliputi uji normalitas, uji multikololinieritas, uji heteroskedastisitas dan uji autokorelasi. Hasil asumsi klasik dapat dilihat pada Tabel 4. berikut. 
Tabel 4.

Hasil Uji Asumsi Klasik

\begin{tabular}{|c|c|c|c|c|c|}
\hline \multirow{2}{*}{$\begin{array}{l}\text { Parameter } \\
\text { yang Diuji }\end{array}$} & \multicolumn{3}{|c|}{$\begin{array}{c}\text { Uji } \\
\text { Multikolonieritas }\end{array}$} & \multirow[t]{2}{*}{$\begin{array}{c}\text { Uji } \\
\text { Heteroskedastisitas }\end{array}$} & \multirow[t]{2}{*}{$\begin{array}{c}\text { Uji } \\
\text { Autokorelasi }\end{array}$} \\
\hline & $\begin{array}{l}\text { Asymp. } \\
\text { Sig. (2- } \\
\text { tailed) }\end{array}$ & Tolerance & VIF & & \\
\hline $\begin{array}{l}\text { Unstandardized } \\
\text { Residual }\end{array}$ & 0,103 & & & & \\
\hline ETR (X1) & & 0,896 & 1,116 & 0,496 & \\
\hline DISC(X2) & & 0,999 & 1,001 & 0,789 & \\
\hline $\begin{array}{l}\text { ETR(X1)*DISC } \\
(\mathrm{X} 2)\end{array}$ & & 0,895 & 1,117 & 0,385 & \\
\hline Durbin-Watson & & & & & 1,977 \\
\hline
\end{tabular}

Uji normalitas bertujuan untuk menguji variabel pengganggu atau residual dalam model regresi memiliki distribusi normal atau tidak. Model regresi yang baik adalah distribusi datanya normal. Pengujian normalitas pada peneltian ini menggunakan uji statistik nonparametik Kolmogrov-Smirnov. Data penelitian dikatakan berdistribusi normal apabila koefisien Asymp. Sig (2-tailed) lebih besar daripada $\alpha=0,05$.

Berdasarkan Tabel 4. di atas, hasil uji Kolmogrov-Smirnov sebesar 1,217 dengan nilai signifikan sebesar 0,103. Dapat disimpulkan bahwa ketiga variabel yaitu penghindaran pajak, transparansi dan nilai perusahaan memiliki data terdistribusi normal sehingga asumsi normalitas sudah terpenuhi.

Uji multikolinieritas bertujuan untuk menguji apakah model regresi ada korelasi antar variabel bebas (independent). Model regresi dikatakan baik apabila tidak terjadi korelasi diantara variabel bebas. Uji multikolinieritas dilakukan dengan melihat nilai Tolerance lebih dari 0,10 dan Variance Inflation Faktor (VIF) kurang dari 10, maka tidak terdapat multikolinieritas. 
Berdasarkan Tabel 4. dapat dilihat bahwa nilai tolerance tiap variabel lebih besar dari 0,10 dan nilai VIF lebih kecil dari 10. Hal tersebut menunjukkan bahwa tidak terjadi multikolinieritas antara kedua variabel bebas dan menggambarkan asumsi multikolinieritas terpenuhi.

Uji heteroskedastisitas bertujuan untuk mengetahui apakah dalam model regresi terjadi ketidaksamaan variance dari residual satu pengamatan ke pengamatan lain. Untuk mendeteksi masalah tersebut dilakukan uji Glesjer yaitu dengan meregresi nilai absolute residual model yang destimasi terhadap variabelvariabel independen dengan memerlihatkan nilai t-statistik dan signifikannya. Suatu model regresi dikatakan tidak mengandung heteroskedastisitas apabila nilai signifikannya di atas 0,05 .

Berdasarkan Tabel 4. dapat diketahui bahwa nilai signifikansi dari masingmasing variabel bebas lebih besar dari 0,05 ini berarti bahwa semua variabel bebas tidak memiliki hubungan dengan nilai residunya, maka hal ini menunjukkan bahwa tidak terjadi heteroskedastisitas pada data penelitian yang digunakan.

Uji autokorelasi bertujuan untuk menguji apakah dalam model regresi linier ada korelasi antara kesalahan pengganggu pada periode $\mathrm{t}$ dengan kesalahan pengganggu pada pada periode t-1 (sebelumnya). Autokorelasi dideteksi ada atau tidaknya dengan cara melihat nilai Durbin Watson (DW) yaitu dengan membandingkan nilai Durbin Watson yang dihitung dengan $\mathrm{d}_{\mathrm{L}}$ dan $\mathrm{d}_{\mathrm{U}}$ yang ada dalam tabel.

Berdasarkan Tabel 4. menunjukkan nilai DW sebesar 1,977. Nilai dU untuk jumlah sampel (N) sebanyak 180 dengan variabel bebas (k) sebanyak 2 adalah 
Made Caesar Juliartha Nugraha dan Putu Ery Setiawan. Pengaruh...

sebesar 1,7786, maka nilai $4<\mathrm{dU}$ yang di dapat adalah 2,023. Hasil uji autokorelasi adalah dU $<\mathrm{DW}<4-\mathrm{dU}$ yaitu $1,7786<1,977<2,023$. Dengan demikian hasil tersebut menunjukkan bahwa model regresi tersebut bebas dari autokorelasi.

Penelitian ini menggunakan Moderated Regression Analysis (MRA) dalam model persamaan regresi linear berganda untuk mengetahui kemampuan transparansi dalam memoderasi pengaruh penghindaran pajak terhadap nilai perusahaan. Hasil analisis regresi moderasi disajikan pada Tabel 5.

Berdasarkan Tabel 5. maka dapat dibuat persamaan regresi linier moderasi sebagai berikut:

$$
Y=0,269+0,754 X_{1}+1,970 X_{2}+0,638\left(X_{1} X_{2}\right)+\varepsilon
$$

Tabel 5.

Hasil Uji Moderating Regression Analysis

\begin{tabular}{|c|c|c|c|c|c|c|}
\hline \multirow{2}{*}{ Model } & \multicolumn{2}{|c|}{$\begin{array}{c}\text { Unstandardized } \\
\text { Coefficients }\end{array}$} & \multirow{2}{*}{$\begin{array}{c}\begin{array}{c}\text { Standardized } \\
\text { Coefficients }\end{array} \\
\text { Beta }\end{array}$} & \multirow{2}{*}{$t$} & \multirow{2}{*}{ Sig. } & \multirow{2}{*}{$\begin{array}{l}\text { Hasil Uji } \\
\text { Hipotesis }\end{array}$} \\
\hline & $\boldsymbol{B}$ & $\begin{array}{c}\text { Std. } \\
\text { Error }\end{array}$ & & & & \\
\hline (Constant) & 0,269 & 2,036 & & 0,132 & 0,895 & \\
\hline ETR (X1) & 0,754 & 0,201 & 0,285 & 3,747 & 0,000 & H1 Diterima \\
\hline DISC (X2) & 1,970 & 2,462 & 0,058 & 0,800 & 0,425 & \\
\hline ETR*DISC (X1X2) & 0,638 & 0,249 & 0,195 & 2,560 & 0,011 & H2 Diterima \\
\hline $\mathrm{R}$ & 0,239 & & & & & \\
\hline$R$ Square & 0,086 & & & & & \\
\hline Adjusted R Square & 0,070 & & & & & \\
\hline F Hitung & 5,522 & & & & & \\
\hline Sig. F & 0,001 & & & & & \\
\hline
\end{tabular}

Nilai konstan sebesar 0,269 memiliki arti bahwa bila nilai variabel independen (penghindaran pajak dan transparansi) tidak ada atau bernilai 0, maka besarnya nilai perusahaan adalah sebesar 0,269 . Nilai koefisien $\left(X_{1}\right)$ sebesar 0,754 menunjukkan bahwa jika nilai ETR meningkat satu satuan maka nilai perusahaan 
akan meningkat sebesar 0,754 dengan asumsi variabel independen lainnya konstan. Nilai koefisien $\left(\mathrm{X}_{2}\right)$ sebesar 1,970 menunjukkan bahwa jika transparansi meningkat satu satuan maka nilai perusahaan akan meningkat sebesar 1,970 dengan asumsi variabel independen lainnya konstan. Nilai koefisien $\left(\mathrm{X}_{1} \mathrm{X}_{2}\right)$ sebesar 0,638 menunjukkan bahwa apabila interaksi antara ETR dengan transparansi meningkat satu satuan, maka nilai perusahaan nilai perusahaan akan meningkat sebesar 0,638 dengan asumsi variabel lainnya konstan.

Berdasarkan Tabel 5. menunjukkan bahwa besarnya nilai Adjusted $R$ Square sebesar 0,070 yang memiliki arti bahwa variabel penghindaran pajak dan transparansi mampu mempengaruhi nilai perusahaan sebesar $7,0 \%$. Sedangkan sisanya sebesar 93,0\% dipengaruhi oleh variabel lain yang tidak dimaksukkan dalam penelitian ini.

Berdasarkan Tabel 5. menunjukkan bahwa nilai $\mathrm{F}$ hitung sebesar 5,522 dengan tingkat signifikansi sebesar 0,001. Nilai tersebut lebih kecil dari $\alpha=0,05$. Hal ini menunjukkan bahwa model persamaan dalam penelitian ini layak untuk digunakan.

Berdasarkan Tabel 5. di atas dapat dilihat bahwa nilai t hitung ETR $\left(\mathrm{X}_{1}\right)$ sebesar 3,747 dengan tingkat signifikansi sebesar 0,000 lebih kecil dari $\alpha=0,05$. Hasil ini menunjukkan bahwa ETR berpengaruh positif terhadap nilai perusahaan. Dengan demikian maka $\mathrm{H}_{1}$ diterima.

Hipotesis pertama $\left(\mathrm{H}_{1}\right)$ tentang penghindaran pajak memiliki pengaruh pada nilai perusahaan. Berdasarkan analisis regresi moderasi diperoleh nilai $\mathrm{X}_{1}$ sebesar 0,754 yang menunjukkan arah positif pada ETR yang menandakan semakin kuat 
nilai perusahaan dengan nilai signifikansi sebesar 0,000 yang lebih kecil dari $\alpha=$ 0,05. Hal ini berarti penghindaran pajak berpengaruh positif pada nilai perusahaan.

Penghindaran pajak (tax avoidance) merupakan alat untuk melakukan tax saving dengan mengalihkan sumber daya yang seharusnya untuk negara diberikan untuk pemegang saham agar nilai after tax (nilai laba setelah pajak) perusahaan meningkat. Ketika nilai after tax meningkat, maka perusahaan dapat memberikan keuntungan penyertaan modal lebih banyak kepada pemegang saham. Pemberian keuntungan ini nantinya dapat meningkatkan loyalitas perusahaan sehingga dapat diindikasikan nilai perusahaan akan meningkat

Hasil penelitian ini sejalan dengan penelitian yang telah dilakukan oleh Hanlon dan Slemrod (2009) dimana perilaku penghindaran pajak berpengaruh positif pada nilai perusahaan pada perusahaan yang mampu mengelola perusahaannya dengan baik. Hasil ini juga didukung oleh penelitian yang dilakukan oleh Anggoro dan Septiani (2015), Kurniawan dan Syafruddin (2017), Dewi (2017), dan Wang (2010) menyatakan bahwa penghindaran pajak berpengaruh positif pada nilai perusahaan

Berdasarkan hasil pengujian pada Tabel 5. pengaruh variabel interaksi antara ETR dengan transparansi terhadap nilai perusahaan menunjukkan nilai $\mathrm{t}$ hitung sebesar 2,560 dengan tingkat signifikansi sebesar 0,011 yang lebih kecil dari $\alpha=0,05$ artinya transparansi mampu memoderasi pengaruh penghindaran pajak terhadap nilai perusahaan. Dengan demikian maka $\mathrm{H}_{2}$ diterima. 
Berdasarkan hasil analisis regresi moderasi pada Tabel 5. menunjukkan nilai $\mathrm{X}_{1} \mathrm{X}_{2}$ sebesar 0,638 nilai t hitung sebesar 2,560 yang menunjukkan arah positf yang menandakan transparansi memoderasi pengaruh penghindaran pajak pada nilai perusahaan dengan nilai signifikansi sebesar 0,011 lebih kecil dari $\alpha=$ 0,05, maka hipotesis kedua $\left(\mathrm{H}_{2}\right)$ diterima. Hal ini berarti transparansi mampu memoderasi pengaruh penghindaran pajak pada nilai perusahaan.

Semakin transparan suatu perusahaan maka nilai perusahaan juga akan meningkat. Semakin banyak informasi yang diungkapkan oleh pihak manajemen pada laporan keuangannya, maka investor dapat lebih mengetahui bagaimana kondisi perusahaan sebenarnya. Kemudahan dalam akses informasi tersebut juga menjadi sinyal positif bagi investor.

Akses informasi tersebut dianggap oleh investor sebagai cara mudah untuk memperhatikan perilaku oportunistik dari manajemen dalam melakukan tindakan penghindaran pajak sehingga menurunkan risiko yang timbul dari kegiatan penghindaran pajak. Kondisi tersebut juga akan memberikan kesan yang positif kepada pihak luar serta calon investor dan hal tersebut juga dapat membantu meningkatkan nilai perusahaan.

Hasil penelitian ini sejalan dengan penelitian yang telah dilakukan olehIlmiani dan Sutrisno (2014) serta Prasiwi (2015) yang menemukan bahwa transparansi berpengaruh serta mampu memoderasi penghindaran pajak terhadap nilai perusahaan. Hal ini diakibatkan, kian banyak informasi yang diungkapkan oleh manajemen pada laporan keuangan atau tahunannya, maka investor maupun pemilik perusahaan dapat lebih mengetahui bagaimana kondisi perusahaan 
sebenarnya. Penelitian yang dilakukan oleh Dewi dan Dewi (2017), Anggoro dan Septiani (2015), Akhunianov (2009), Pradnyana dan Noviari (2017) juga memeroleh bukti emipiris yang sama.

\section{SIMPULAN}

Berdasarkan pembahasan hasil penelitian di atas, dapat disimpulkan bahwa Penghindaran pajak berpengaruh positif terhadap nilai perusahaan. Hasil ini membuktikan bahwa tindakan penghindaran pajak (tax avoidance) dapat meningkatkan minat investor dalam berinvestasi serta memberikan return saham yang lebih besar kepada investor. Pemberian keuntungan ini nantinya dapat meningkatkan loyalitas perusahaan sehingga dapat diindikasikan nilai perusahaan akan meningkat. Transparansi mampu memoderasi hubungan antara tax avoidance terhadap nilai perusahaan. Hasil ini membuktikan bahwa perusahaan yang transparan mempunyai informasi yang dapat diakses oleh investor ketika diperlukan, dengan adanya transparansi informasi maka akan menurunkan risiko yang timbul dari kegiatan penghindaran pajak. Hal tersebut menjadi sinyal positif bagi investor dan dapat membantu meningkatkan nilai perusahaan. Sedangkan saran yang dapat diberikan adalah bagi pihak Direktorat Jenderal Pajak diharapkan untuk menyempurnakan aturan perundang undangan mengenai perpajakan. Agar ketentuan penangkal praktik penghindaran pajak (tax avoidance) dapat digunakan secara efektif untuk menangkal praktik-praktik penghindaran pajak. Bagi perusahaan diharapkan agar lebih transparan dalam pengungkapan informasi mengenai kondisi perusahaan pada pihak stakeholder, sehingga dapat meningkatkan nilai perusahaan. 


\section{REFERENSI}

Aina, Q. 2016. Analisis Pengaruh Penghindaran Pajak Terhadap Nilai Perusahaan dengan Kepemilikan Institusional dan Transparansi sebagai Variabel Pemoderasi. Administrasi Bisnis, 36(1), 101-110.

Akhunianov, I. 2009. Transparency and Firm Value : Evidence from the Financial Crisis. New Economic School.

Alabede, J. O., Ariffin, Z. Z., \& Idris, K. M. 2011. Individual taxpayers attitude and compliance behaviour in Nigeria: The moderating role of financial condition and risk preference. Journal of Accounting and Taxation, 3(September), 91-104.

Anggoro, S. T., \& Septiani, A. 2015. Analisis Pengaruh Perilaku Penghindaran Pajak Terhadap Nilai Perusahaan Dengan Transparansi Sebagai Variabel Moderating. Diponegoro Journal of Accounting, 4(4), 1.

Armstrong, C. S., Blouin, J. L., \& Larcker, D. F. 2015. Corporate Governance , Incentives, and Tax Avoidance. Accounting Papper, 60, 1-17.

Bushman, R.M. \& A.J. Smith. 2003. Transparency, Financial Accounting Information and Coroporate Governance. Economic Policy Review.

Chasbiandani, T., \& Martani, D. 2012. Pengaruh Tax Avoidance Jangka Panjang Terhadap Nilai Perusahaan. SNA XV Banjarmasin, 1-27.

Chen, S., Chen, X., \& Cheng, Q. 2010. Are Family Firms more Tax Aggressive than Non- family Firms? Journal of Financial Economics, 95(1), 41-61.

Chen, Xudong, Na Hu, Xue Wang dan Xiaofei Tang. 2014. Tax Avoidance and Firm Value: Evidence From China. Nankai Business Review International

Desai, M. A., \& Dharmapala, D. 2005. Corporate Tax Avoidance and Firm Value. The Review Of Economic and Statistic.

Dewi, Ni Komang Trie Julianti dan Ni Ketut Lely Aryani Merkusiwati. 2016. Faktor-faktor Yang Mempengaruhi Persepsi Wajib Pajak Mengenai Etika Atas Penggelapan Pajak ( Tax Evasion). Universitas Udayana.

Dewi, A. A., \& Dewi, L. G. K. 2017. Transparasi Informasi Memoderasi Pengaruh Agresivitas Pajak Pada Nilai Perusahaan Pertambangan di Bursa Efek Indonesia. Akuntabilitas, 10(2), 211-230. 
Dharma, I. M. S. 2016. Pengaruh Leverage, Intesitas Aset Tetap, Ukuran Perusahaan dan Koneksi Politik terhadap Tax Avoidance. Universitas Udayana, 15, 584-613.

Dwiyanti, R. 2010. Analisis Faktor-Faktor Yang Mempengaruhi Ketepatan Waktu Pelaporan Keuangan Pada Perusahaan Manufaktur Yang Terdaftar Di Bursa Efek Indonesia. Semarang : Universitas Diponegoro, 112.

Dyreng, S. D., Hanlon, M.; \& Maydew, E. L. 2008. Long-Run Corporate Tax Avoidance. The Accounting Review, 83(1), 61.

Ftouhi, K., Ayed, A., \&Zemzem, A. 2015. Tax Planning and Firm Value: Evidence from European Companies. International Journal Economics \& Strategic Management of Business Process, 4(March), 1-5.

Eisenhardt, K.M. 1998. Agency Theory: An Assessment and Review. Academy of Management Review, 14 (1):h:57-74.

Frank, M., Lynch, L., \&Rego, S. 2009. Tax reporting aggressiveness and its relation to aggressive financial reporting. The Accounting Review

Ghozali, Imam. 2016. Aplikasi Analisis Multivariative Dengan Program IBM SPSS 23. Semarang: Badan Penerbit Universitas Diponogoro.

Hanlon, M., \& Slemrod, J. 2009. What does tax aggressiveness signal? Evidence from stock price reactions to news about tax shelter involvement. Journal of Public Economics, 93(1-2), 126-141.

Hendrikzen, Eldon S.,\& M.F Van Breda. 1992. Accounting Teory. USA: Richard D. Irwin Inc.

Ilmiani, A., \& Sutrisno, C. R. 2014. Pengaruh Tax Avoidance terhadap Nilai Perusahaan dengan Transparansi Perusahaan sebagai Variabel Moderating Amalia Ilmiani Fakultas Ekonomi Universitas Pekalongan Catur Ragil Sutrisno Fakultas Ekonomi Universitas Pekalongan, 14, 30-39.

Jacob, F. 2014. An Empirical Study of Tax Evasion and Tax Avoidance: A Critical Issue in Nigeria Economic Development. Issn, 5(18), 22-27.

Jama'an. 2008. Pengaruh Mekanisme Corporate Governance Dan Kualitas Kantor Akuntan Publik Terhadap Integritas Informasi Laporan Keuangan. Jurnal Universitas Diponegoro, 1(1), 1-52.

Jensen, M. C., \& Meckling, W. H. 1976. Also published in Foundations of Organizational Strategy. Journal of Financial Economics, (4), 305-360. 
Kirchler, E., Maciejovsky, B., \& Schneider, F. 2003. Everyday representations of tax avoidance, tax evasion, and tax flight: Do legal differences matter? Journal of Economic Psychology, 24(4), 535-553.

Kurniasih, T., \& Sari, M. M. R. 2013. Pengaruh Return on Assets , Leverage , Corporate Governance, Ukuran Perusahaan Dan Kompensasi Rugi Fiskal Pada Tax Avoidance (The Effect of Return on Asset, Leverage, Corporate Governance, Company Size, and Fiscal Loss Compensation in Tax Avoidance). Buletin Studi Ekonomi, 18(1), 58-66.

Kurniawan, A. F., \& Syafruddin, M. 2017. Pengaruh Penghindaran Pajak Terhadap Nilai Perusahaan dengan Variabel Moderasi Transparansi. Diponegoro Journal of Accounting, 6(4), 1-10.

Lim, Y. 2011. Tax avoidance, cost of debt and shareholder activism: Evidence from Korea. Journal of Banking and Finance, 35(2), 456-470.

Muhammad, B. 2012. Analisis Pengaruh Strategi Bisnis Perusahaan Terhadap Tingkat Penghindaran Pajak Pada Perusahaan Manufaktur Yang Terdaftar Di BEI. Universitas Indonesia.

Mulyani, S., Darminto., dan Endang, M.W. 2014. Pengaruh Karakteristik Perusahaan, Koneksi Politik dan Reformasi Perpajakan Terhadap Penghindaran Pajak (Studi pada perusahaan manufaktur yeng terdaftar di BEI tahun 2008-2012). Jurnal Mahasiswa Perpajakan Universitas Brawijaya.

Olaofe, E. O. 2008. Overview of tax administration dan three tiers of goverment in Nigeria. ICAN Students Journal.

Partha, I Gede Angga \& Noviari Naniek. 2016. Pengaruh Penghindaran Pajak Jangka Panjang pada Nilai Perusahaan dengan Transparansi Informasi Sebagai Variabel Pemoderasi. E-jurnal Akuntansi Universitas Udayana.

Pradnyana, I. B. G. P., \& Noviari, N. 2017. Pengaruh Perencanaan Pajak Terhadap Nilai Perusahaan dengan Transparansi Perusahaan sebagai Variabel Moderasi. E-Jurnal Akuntansi Universitas Udayana, 18(2), 13981425 .

Prasiwi, K. W. 2015. Pengaruh Penghindaran Pajak Terhadap Nilai Perusahaan: Transparansi Informasi Sebagai Variabel Pemoderasi. Skripsi Fakultas Ekonomika dan Bisnis Universitas Diponegoro Disusun.

Rikotama, G. 2018. Pengaruh Penghindaran Pajak Jangka Panjang Terhadap Nilai Perusahaan dengan Kepemilikan Saham Institusional Sebagai Variabel 
Made Caesar Juliartha Nugraha dan Putu Ery Setiawan. Pengaruh...

Pemoderasi. Universitas Udayana, 23, 927-956.

Ross, S. A. 1977. The Determination of Financial Structure: The Incentive Signalling Approach. Bell Journal of Economics, 8(1), 23-40.

Schift, M. \& A.W. Lewin. 1970. The Impact of People on Budgets. The Accounting Review.

Siregar, D. R. 2012. Analisis Pengaruh Penghindaran Pajak Terhadap Nilai Perusahaan dengan Kepemilikan Institusional dan Kepemilikan Keluarga sebagai Variabel Moderasi. Universitas Indonesia.

Sukamulja, S. 2004. Good Corporate Governance Di Sektor Keuangan: Dampak GCG Terhadap Kinerja Perusahaan ( Kasus di Bursa Efek Jakarta ). Benefit, Fakultas Ekonomi Universitas Atma Jaya Yogyakarta, 8(1), 1-25.

Surbakti, Theresa Adelina Victoria. 2012. Pengaruh Karakteristik Perusahaan dan Reformasi Perpajakan Terhadap Penghindaran Pajak di Perusahaan Industri Manufaktur yang Terdaftar di BEI 2008-2010. Jurnal Akuntansi Fakultas Ekonomi Universitas Indonesia.

Tarihoran, A. 2016. Pengaruh Penghindaran Pajak dan Leverage terhadap Nilai Perusahaan dengan Transparansi Perusahaan sebagai Variabel Moderasi. Jurnal Wira Ekonomi Mikroskil, 6(2), 149-164.

Thiono, H. 2006. Perbandingan Keakuratan Model Arus Kas Metoda Langsung dan Tidak Langsung Dalam Memprediksi Arus Kas dan Deviden Masa Depan. Simposium Nasional Akuntansi Padang, 23-26.

Tobin, Prof. James. 1967. Tobin's Q Ratio As An Indicator of the valuation ofthe company. Journal of Financial Economics.

Wang, Tina. 2010. Tax Avoidance, Corporate Transparency, and Firm Value. University of Texas at Austin.

Wang, Xiaohang. 2010. Tax Avoidance, Corporate Transparency, and Firm Value. Disertasi. University of Texas at Austin.

Wolk, Harry, Michael G. Tearney, \& James L DoMdd. 2000. Accounting Theory: A Conceptual and Institutional Approach. South-Western: College Publishing.

Xynas, L. 2011. Tax Planning, Avoidance and Evasion in Australia 1970-2010: The Regulatory Responses and Taxpayer Compliance. Revenue Law Journal, 20(1), 2 . 